\title{
PENGARUH JARAK TANAM DAN DOSIS BIO-URIN TERHADAP PERTUMBUHAN DAN HASIL RUMPUT Panicum maximum PADA PEMOTONGAN KETIGA
}

\author{
Kusumawati, N.N.C., N.M. Witariadi, I K.M Budiasa, \\ I G. Suranjaya dan N.G.K. Roni \\ Fakultas Peternakan Univ. Udayana \\ Email:candraasihkusuma@gmail.com
}

\begin{abstract}
ABSTRAK
Tujuan penelitian ini adalah untuk mengetahui terjadi interaksi antara perlakuan jarak tanam dan dosis bio urin pada pemotongan ketiga serta, bagaimana pertumbuhan rumput dan hasil hijauan rumput Panicum maximum pada pemotongan ketiga.Percobaan ini, dirancang dengan rancangan acak kelompok (RAK) faktorial, dua faktor dengan tiga ulangan. Dosis pupuk bio urin yaitu $0,3.750 \mathrm{l} \mathrm{ha}^{-1}$, 7.500 1 ha $^{-1}$ dan $11.250 \mathrm{l} \mathrm{ha}^{-1}$ adalah faktor pertama, sedangkan jarak tanam $10 \mathrm{~cm} \mathrm{x} 20 \mathrm{~cm}, 20 \mathrm{~cm} \times 20 \mathrm{~cm}, 40 \mathrm{~cm}$ x $20 \mathrm{~cm}$ adalah faktor kedua. Hasil percobaan menunjukkan bahwa interaksi jarak tanam dan dosis bio urin berpengaruh nyata $(\mathrm{P}<0,05)$ terhadap pertumbuhan rumput Panicum maximum pada variabel tinggi tanaman dan jumlah anakan. Jarak tanam dan dosis pupuk bio urin berpengaruh nyata $(\mathrm{P}<0,05)$ terhadap hasil rumput Panicum maximum pada variabel berat kering stabel, daun, batang, bunga, nisbah daun batang dan berat kering total hijauan. Hasil berat kering hijauan yang paling baik pada jarak tanam $J_{1}(10 \mathrm{~cm} x$ $20 \mathrm{~cm}$ ) dengan dosis bio urin D2 $\left(7.500 \mathrm{l} \mathrm{ha}^{-1}\right.$ ) pada pemotongan ketiga. Kesimpulan dari penelitian ini adalah Terjadi interaksi antara jarak tanam dengan dosis bio urin terhadap pertumbuhan dan hasil rumput Panicum maximum pada pemotongan ketiga dengan hasil paling baik pada jarak tanam $\mathrm{J}_{1}$ dengan dosis bio urin D2 dengan total hasil hijauan 7,90 ton ha $^{-1}$ pada pemotongan ketiga.
\end{abstract}

Kata kunci: jarak tanam, bio urin, Panicum maximum

\section{PENDAHULUAN}

Penanaman hijauan pakan lebih banyak dilakukan di lahan kering yang produktivitasnya rendah, akibat kekurang air dan rendahnya kesuburan tanah sehingga perlu diberikan input dari luar, salah satunya dengan pemberian bio urin. Pada musim kemarau di lahan kering sering kekurangan hijauan makanan ternak, sehingga perlu dikembangkan rumput unggul yang tahan kekeringan. Rumput unggul adalah rumput yang dipilih dan dikembangkan untuk tumbuh cepat dan menghasilkan bahan kering yang tinggi, dengan kualitas yang baik sehingga dapat memenuhi kebutuhan ternak ruminansia (Mc. Illroy, 1997).

Salah satu rumput unggul yang mampu beradaptasi di lahan kering adalah rumput Panicum maximum. Selain beradaptasi di lahan kering juga cepat tumbuh, produksi dan kandungan protein kasarnya tinggi, sangat disenangi oleh ternak serta sangat responsive terhadap pemupukan (Nitis, 1980). Mendapatkan hasil rumput Panicum yang maksimal diperlukan pemberian input dari luar dan pengaturan jarak tanam yang tepat. Panicum maximum memerlukan unsur hara yang optimal untuk pertumbuhan dan hasil yang maksimal, salah satu sumber hara makro dan mikro yang dapat langsung tersedia bagi tanaman dapat dilakukan dengan pemberian pupuk bio urin.
Bio urin merupakan pupuk organik yang belum banyak dimanfaatkan oleh petani peternak. Dengan pemberian dosis bio urin yang tepat diharapkan dapat meningkatkan hasil rumput Panicum maximum.

Selain pemberian input dari luar diperlukan pula pengaturan jarak tanam yang tepat untuk memperkecil persaingan, memaksimalkan produksi, serta meningkatkan produktivitas lahan. Jarak tanam yang terlalu rapat akan menekan pertumbuhan rumput, sedangkan jarak tanam yang terlalu renggang kurang effisien dalam pemanfaatan lahan sehingga berpotensi mengurangi keuntungan.

Penanaman rumput Panicum maximum apabila diberikan pupuk organik bio urine dengan dosis yang optimal dengan kombinasi pengaturan jarak tanam yang tepat, akan menghasilkan petumbuhan dan hasil yang maksimal. Dimana bahan organik akan berpengaruh langsung terhadap fisiologi tanaman, meningkatkan aktivitas biologi tanah dan juga meningkatkan ketersediaan air tanah. Semakin tinggi kadar air tanah maka absorbsi dan transportasi unsur hara dan air akan lebih baik sehingga laju fotosintesis untuk dapat menghasilkan cadangan makananan bagi tanaman akan lebih terjamin. Serta didukung oleh pengaturan jarak tanam yang baik akan mendapatkan kerapatan tanaman yang optimum, sehingga kompetisi penyerapan hara antara tanaman 
rumput dapat diminimalkan. Dihasilkan Indek Luas Daun yang optimum dengan pembentukan berat kering yang maksimal. Sehingga kekurangan hijauan makanan ternak pada musim kemarau dapat diatasi.

Informasi tentang hasil penelitian jarak tanam dan pemberian pupuk bio urin pada rumput masih sangat terbatas, oleh karena itu penelitian tentang aspek tersebut perlu dilakukan pada rumput Panicum maximum yang merupakan salah satu tanaman rumput yang dapat beradaptasi di lahan kering.

Tujuan penelitian ini adalah : 1) Mengetahui pengaruh interaksi antara jarak tanam rumput dengan dosis bio urin terhadap pertumbuhan dan hasil rumput Panicum maximum pada pemotongan ketiga. 2) Mengetahui jarak tanam yang terbaik terhadap pertumbuhan dan hasil rumput Panicum maximum pada pemotongan ketiga. 3) Mengetahui dosis bio urin yang terbaik terhadap pertumbuhan dan hasil rumput Panicum maximum pada pemotongan ketiga.

\section{METODE PENELITIAN}

Rancangan Percobaan : Rancangan percobaan yang digunakan dalam penelitian ini adalah Rancangan Acak Kelompok (RAK) faktorial. Pola 2 Faktor yaitu: Faktor Jarak tanam terdiri dari $\mathrm{J} 1=10 \mathrm{~cm} \times 20 \mathrm{~cm}$, $\mathrm{J}_{2}=20 \mathrm{~cm} \times 20 \mathrm{~cm}, \mathrm{~J}_{3}=40 \mathrm{~cm} \times 20 \mathrm{~cm}$. Faktor dosis Bio-urine (D) terdiri dari Do = Tanpa Bio-urin, $\mathrm{D} 1=3.750 \mathrm{l} \mathrm{ha}^{-1}\left(1,44 \mathrm{l} \mathrm{petak}^{-1}\right), \mathrm{D} 2=7.500 \mathrm{l} \mathrm{ha}^{-}$ ${ }^{1}\left(2,88\right.$ l petak $\left.^{-1}\right), \mathrm{D}_{3}=11.250 \mathrm{l} \mathrm{ha}^{-1}\left(4,32 \mathrm{l} \mathrm{petak}^{-1}\right)$.

Lokasi dan Waktu Penelitian : Penelitian dilaksanakan di Dusun Suka Hati, Desa Pasinggahan, Kecamatan Dawan, Kabupaten Klungkung. Waktu penelitian adalah dari Bulan Desember 2010 sampai Mei 2011.

Variabel Pengamatan : Variabel yang diamati meliputi variabel pertumbuhan dan variabel hasil. Variabel Pertumbuhan meliputi: Tinggi tanaman, Jumlah anakan, Jumlah daun, Warna daun, Variabel Hasil meliputi: Berat kering daun, Berat kering batang, berat kering total hijauan, berat kering stable, nisbah berat kering daun dengan berat kering batang dan Berat kering bunga.

Analisa Data : Data yang diperoleh dianalisis dengan sidik ragam dan apabila perlakuan menunjukkan perbedaan yang nyata $(\mathrm{P}<0,05)$, maka perhitungan dilanjutkan dengan uji jarak berganda dari Duncan (Steel dan Torrie, 1993).

\section{HASIL DAN PEMBAHASAN}

Hasil penelitian menunjukkan terjadi interaksi antara perlakuan jarak tanam dengan dosis pupuk bio urin terhadap pertumbuhan dan hasil rumput Panicum maximum pada pemotongan ketiga di lahan
Tabel 1. Pertumbuhan Rumput Panicum maximum yang Ditanam dengan Jarak Tanam dan Dosis Bio Urin Berbeda pada Lahan Kering

\begin{tabular}{|c|c|c|c|c|c|}
\hline \multirow{2}{*}{ Variabel } & \multirow{2}{*}{$\begin{array}{c}\text { Dosis } \\
\text { Pupuk }^{3)}\end{array}$} & \multicolumn{3}{|c|}{ Jarak Tanam 2) } & \multirow{2}{*}{ Rata-rata } \\
\hline & & J1 & $\mathrm{J} 2$ & $\mathrm{J3}$ & \\
\hline \multirow{4}{*}{$\begin{array}{l}\text { Tinggi } \\
\text { Tanaman }\end{array}$} & BO & 75,07 & 75,97 & 72,40 & $74,47 b^{1)}$ \\
\hline & B1 & 77,73 & 77,43 & 75,23 & $76,8 \mathrm{ab}$ \\
\hline & B2 & 78,73 & 85,20 & 76,60 & $80,17 a$ \\
\hline & B3 & 86,93 & 78,77 & 77,77 & $81,15 a$ \\
\hline \multicolumn{2}{|c|}{ Rata-Rata } & $79,61 a$ & $79,34 a b$ & $75,5 b$ & \\
\hline Jumlah & BO & 8,57 & 8,80 & 10,13 & $9,16 \mathrm{c}$ \\
\hline \multirow[t]{3}{*}{ Anakan } & B1 & 10,23 & 11,33 & 10,93 & $10,83 b$ \\
\hline & $\mathrm{B} 2$ & 9,90 & 14,47 & 12,70 & $12,35 a$ \\
\hline & B3 & 10,23 & 14,03 & 12,10 & $12,12 \mathrm{ab}$ \\
\hline \multicolumn{2}{|c|}{ Rata-rata } & $9,73 b$ & $12,15 a$ & $11,46 a$ & \\
\hline Jumlah & BO & 44,53 & 43,73 & 45,77 & $44,67 b$ \\
\hline \multirow[t]{3}{*}{ Daun } & B1 & 49,33 & 46,00 & 49,37 & $48,23 a$ \\
\hline & $\mathrm{B} 2$ & 51,80 & 53,13 & 53,43 & $52,78 a$ \\
\hline & B3 & 49,10 & 51,53 & 51,90 & $50,84 a$ \\
\hline \multicolumn{2}{|c|}{ Rata-rata } & $48,69 a$ & $48,6 a$ & $50,11 a$ & \\
\hline Warna & $\mathrm{BO}$ & 4,33 & 4,33 & 4,67 & $4,44 b$ \\
\hline \multirow[t]{3}{*}{ Daun } & B1 & 5,00 & 4,33 & 5,00 & $4,77 b$ \\
\hline & B2 & 6,00 & 5,67 & 5,33 & $5,66 a$ \\
\hline & B3 & 5,67 & 5,67 & 5,67 & $5,66 a$ \\
\hline \multicolumn{2}{|c|}{ Rata-rata } & $5,24 a$ & $5 a$ & $5,16 a$ & \\
\hline
\end{tabular}

Keterangan :

1) Nilai dengan huruf yang sama pada baris atau kolom yang sama menenjukkan berbeda tidak nyata $(P>0,005)$.

2) $J 1=$ jarak tanam $10 \mathrm{~cm} \times 20 \mathrm{~cm}, J 2=20 \mathrm{~cm} \times 20 \mathrm{~cm}, 13=40 \mathrm{~cm} \times 20 \mathrm{~cm}$

3) $\mathrm{DO}=$ Dosis pupuk bio urine $0 \mathrm{I}$ ha $, \mathrm{D} 1=3.750 \mathrm{I} \mathrm{ha}, \mathrm{D} 2=7.500 \mathrm{I} \mathrm{ha}$, D3 $=11.250 \mathrm{I} \mathrm{ha}$

kering. Hal ini mengindikasikan bahwa anatara faktor jarak tanam dan dosis pupuk bio urin dapat secara bersama atau sendiri-sendiri dalam mempengaruhi pertumbuhan dan hasil rumput Panicum maximum. Data Tabel 1 menunjukkan pertumbuhan rumput yang dipupuk bio urin dengan dosis $11.250 \mathrm{l} \mathrm{ha}^{-1}$ (D3) memberikan hasil tinggi tanaman, jumlah anakan, jumlah daun yang tinggi namun berbeda tidak nyata dengan D2 $\left(7.500 \mathrm{l} \mathrm{ha}^{-1}\right)$ tetapi nyata lebih tinggi dengan D1 (3.750 $\left.\mathrm{ha}^{-1}\right)$ dan Do. Hal ini karena makin tinggi dosis pupuk bio urin makin tinggi tingkat pertumbuhan tanaman karena semakin tinggi unsur hara yang tersedia bagi tanaman. Pendapat ini didukung oleh Kerley et all (1996) dan Widjajanto at all (2001).

Jarak tanam J2 $(20 \mathrm{~cm} \times 20 \mathrm{~cm})$ menunjukkan hasil tertinggi pada jumlah anakan berbeda tidak nyata dengan $\mathrm{J}_{3}(40 \mathrm{~cm} \times 20 \mathrm{~cm})$ tetapi nyata lebih tinggi dengan $\mathrm{J}_{1}(10 \mathrm{~cm} \times 20 \mathrm{~cm})$. Hal ini karena pada perlakuan $\mathrm{J}_{2}$ dan $\mathrm{J}_{3}$, tanaman lebih banyak mendapat unsur hara dan ruang untuk pertumbuhan anakan. Karena jumlah tanaman lebih sedikit daripada J1. Semakin renggang jarak tanam kompetisi terhadap faktor tumbuh semakin rendah sehingga memberikan pertumbuhan anakan semakin banyak.

Jumlah daun dan warna daun menunjukkan hasil yang berbeda tidak nyata $(\mathrm{P}>0,05)$ diantara 
perlakuan jarak tanam tetapi tinggi tanaman menunjukkan hasil tertinggi pada perlakuan J1 (10 $\mathrm{cm} \times 20 \mathrm{~cm}$ ) namun berbeda tidak nyata dengan $\mathrm{J} 2(20 \mathrm{~cm} \times 20 \mathrm{~cm})$ tetapi nyata lebih tinggi dari $\mathrm{J}_{3}(40 \mathrm{~cm} \times 20 \mathrm{~cm})$. Hal ini karena pada $\mathrm{J} 1$ tanaman lebih banyak memanfaatkan unsure hara untuk pertumbuhan keatas dibanding kesamping seBaliknya pada $\mathrm{J}_{3}(40 \mathrm{~cm} \times 20 \mathrm{~cm}$ ) tanaman lebih banyak untuk pertumbuhan kesamping (anakan). Semakin rapat penanaman kompetisi terhadap ruang semakin ketat sehingga tanaman memaksimalkan tumbuhnya keatas, sehingga tinggi tanaman semakin tinggi. SeBalikknya semakin renggang penanaman tanaman memaksimalkan pertumbuhannya kearah samping (membentuk anakan).

Tabel 2. Produksi Rumput Panicum maximum yang Ditanam dengan Jarak Tanam dan Dosis Bio Urin Berbeda pada Lahan Kering

\begin{tabular}{|c|c|c|c|c|c|}
\hline \multirow{2}{*}{ Variabel } & \multirow{2}{*}{$\begin{array}{l}\text { Dosis } \\
\text { Pupuk }\end{array}$} & \multicolumn{3}{|c|}{ Jarak Tanam²) } & \multirow{2}{*}{ Rata-rata } \\
\hline & & J1 & $\mathrm{J} 2$ & $\mathrm{~J} 3$ & \\
\hline \multirow{4}{*}{$\begin{array}{l}\text { Berat Kering } \\
\text { Total Stabel } \\
\text { (gram) }\end{array}$} & B0 & 5,17 & 6,87 & 5,30 & $5,77 c^{1)}$ \\
\hline & B1 & 5,97 & 7,00 & 6,60 & $6,52 b$ \\
\hline & B2 & 6,23 & 7,17 & 8,87 & $7,42 a$ \\
\hline & B3 & 6,00 & 7,50 & 7,10 & $6,86 a b$ \\
\hline \multicolumn{2}{|c|}{ Rata-Rata } & $5,84 b$ & 7,13a & $6,96 a$ & \\
\hline \multirow{4}{*}{$\begin{array}{l}\text { Berat Kering } \\
\text { Daun (ton/ha) }\end{array}$} & BO & 1,60 & 0,75 & 0,46 & $0,93 c$ \\
\hline & B1 & 2,50 & 1,41 & 0,73 & $1,54 b$ \\
\hline & B2 & 3,38 & 1,68 & 1,01 & $2,02 a$ \\
\hline & B3 & 2,62 & 1,17 & 0,99 & $1,59 b$ \\
\hline \multicolumn{2}{|l|}{ Rata-rata } & $2,52 a$ & $1,25 a$ & $0,79 c$ & \\
\hline \multirow{4}{*}{$\begin{array}{l}\text { Berat Kering } \\
\text { Batang (ton/ha) }\end{array}$} & BO & 1,70 & 0,72 & 0,40 & $0,94 c$ \\
\hline & B1 & 2,58 & 1,14 & 0,69 & $1,46 b c$ \\
\hline & B2 & 3,06 & 1,67 & 0,92 & $1,88 a$ \\
\hline & B3 & 2,54 & 1,12 & 0,98 & $1,54 a b$ \\
\hline \multicolumn{2}{|l|}{ Rata-rata } & $2,46 a$ & $1,16 b$ & $0,75 c$ & \\
\hline \multirow{4}{*}{$\begin{array}{l}\text { Berat Kering } \\
\text { Bunga (ton/ha) }\end{array}$} & BO & 0,74 & 0,29 & 0,19 & $0,40 c$ \\
\hline & B1 & 1,17 & 0,43 & 0,35 & $0,65 b$ \\
\hline & B2 & 1,46 & 0,79 & 0,38 & $0,87 a$ \\
\hline & B3 & 1,21 & 0,49 & 0,42 & $0,70 b$ \\
\hline \multicolumn{2}{|c|}{ Rata-rata } & $1,14 a$ & $0,49 b$ & $0,33 c$ & \\
\hline \multirow{4}{*}{$\begin{array}{l}\text { Nisbah daun } \\
\text { Batang (ton/ha) }\end{array}$} & BO & 0,94 & 1,00 & 1,13 & $1,02 b c$ \\
\hline & B1 & 0,99 & 1,25 & 1,06 & $1,09 b$ \\
\hline & B2 & 1,13 & 1,01 & 1,09 & $1,07 a$ \\
\hline & B3 & 1,02 & 1,10 & 0,99 & $1,03 a b$ \\
\hline \multicolumn{2}{|l|}{ Rata-rata } & $1,02 a$ & $1,09 \mathrm{~b}$ & $1,06 \mathrm{c}$ & \\
\hline \multirow{5}{*}{$\begin{array}{l}\text { Berat Kering } \\
\text { Total Hijauan } \\
\text { (ton/ha) }\end{array}$} & BO & 4,04 & 1,77 & 1,05 & $2,28 \mathrm{c}$ \\
\hline & B1 & 6,25 & 2,98 & 1,77 & $3,66 b$ \\
\hline & B2 & 7,90 & 4,14 & 2,31 & $4,78 a$ \\
\hline & B3 & 6,36 & 2,77 & 2,40 & $3,84 b$ \\
\hline & & $6,13 a$ & $2,91 b$ & $1,88 \mathrm{c}$ & \\
\hline
\end{tabular}

Keterangan :
1) Nilai dengan huruf yang sama pada baris atau kolom yang sama menenjukkan berbeda tidak nyata $(P>0,005)$.

2) $J 1=$ jarak tanam $10 \mathrm{~cm} \times 20 \mathrm{~cm}, J 2-20 \mathrm{~cm} \times 20 \mathrm{~cm}, \mathrm{~L}=40 \mathrm{~cm} \times 20 \mathrm{~cm}-1$

3) $\mathrm{D} 0=$ Dosis pupuk bio urine $0 \mathrm{I}$ ha $, \mathrm{D} 1=3.750 \mathrm{I} \mathrm{ha}, \mathrm{D} 2=7.500 \mathrm{I} \mathrm{ha}$, D3 $=11.250 \mathrm{I} \mathrm{ha}$.

Data pada Tabel 2 menunjukkan bahwa hasil berat kering total stabel, berat kering batang, nisbah daun batang menunjukkan hasil tertinggi pada dosis pupuk bio urin D2 berbeda tidak nyata dengan perlakuan D3 tetapi berbeda nyata dengan perlakuan D1 dan Do. Hasil pada berat kering daun, bunga dan total hijauan tertinggi pada pemupukan bio urin D2 berbeda nyata dengan perlakuan lainnya. Hal ini karena tanaman yang diberi pupuk bio urin dengan dosis D2 dapat memanfaatkan unsur hara secara maksimal. Hal ini didukung oleh adanya berat stabel, daun, batang, dan nisbah daun batang yang tinggi yang mengindikasikan semakin banyak daun akan meningkatkkan proses fotosintesis yang menghasilkan karbohidrat sehingga meningkatkan berat kering tanaman. Pendapat ini didukung oleh Adijaya (2010) yang menyatakan semakin tinggi dosis pupuk bio urin yang diberikan akan meningkatkan N total tanah. Poerwowidodo (1992) Sutejo (2002) menyatakan Nitrogen diperlukan untuk merangsang pertumbuhan vegetatif, memperbesar ukuran daun dan meningkatkan kandungan klorofil. Peningkatan klorofil pada daun akan mempercepat proses fotosintesis yang hasilnya ditranslokasikan ke bagian lain dari tanaman yang akan digunakan untuk pertumbuhan vegetatif dan generatif.

Nisbah berat kering daun batang tertinggi pada pemupukan bio urin D2 hal ini disebabkan oleh hasil berat kering daun yang tinggi. Semakin tinggi nisbah dau batang menunjukkan rumput tersebut memiliki kualitas yang lebih baik, karena kandungan karbohidrat dan protein akan lebih banyak dengan meningkatnya pertumbuhan daun. Rumput Panicum maximum yang ditanam pada jarak tanam $\mathrm{J}_{2}(20 \mathrm{~cm}$ x $20 \mathrm{~cm}$ ) memberikan hasil stabel tertinggi namun berbeda tidak nyata dengan $\mathrm{J}_{3}(40 \mathrm{~cm}$ x $20 \mathrm{~cm})$ tetapi berbeda nyata dengan $\mathrm{J} 1(10 \mathrm{~cm} \times 20 \mathrm{~cm})$. Keadaan ini karena adanya jumlah anakan yang paling tinggi pada perlakuan J2. Semakin banyak anakan semakin banyak batang sehingga semakin berat stabelnya. Semakin berat stabel pada suatu perlakuan sangat mempengaruhi pertumbuhan dan hasil rumput pada panen selanjutnya. Stabel menentukan pertumbuhan kemBali tanaman untuk cadangan makanan selama belum terbentuk daun. Setelah terbentuk daun tanaman mengambil makanan melalui proses fotosintesis. Stabel setelah panen sangat menentukan hasil hijauan rumput Panicum maximum.

Interaksi antara jarak tanam dan dosis bio urin terjadi pada variabel tinggi tanaman, jumlah anakan dan hasil berat kering daun, batang, bunga, nisbah daun batang dan berat kering total hijauan pada pemotongan ketiga. Pada dosis bio urin D1 dan D2 mampu meningkatkan pertumbuhan dan hasil tanaman. semakin tinggi dosis yang diberikan semakin baik. Tetapi pada pemberian dosis pupuk bio urin D3 pada variabel berat kering daun, berat kering bunga dan berat kering total hijauan mengalami penurunan. Hal ini karena pemberian bio urin 
yang lebih menyebabkan pertumbuhan vegetative yang tinggi dengan adanya kandungan $\mathrm{N}$ dari pupuk tersebut, tetapi tanaman bersifat sukulensis dimana tanaman memiliki ukuran batang dan daun serta bunga yang lebih besar namun mengandung kadar air yang tinggi sehingga mempengaruhi berat kering tanaman, sehinggaberat kering total hijauan menjadi menurun.

\section{KESIMPULAN DAN SARAN}

Kesimpulan : Berdasarkan hasil penelitian dapat disimpulkan terjadi interaksi antara jarak tanam dengan dosis bio urin terhadap pertumbuhan dan hasil rumput Panicum maximum yang ditanam di lahan kering pada pemotongan ketiga. Pertumbuhan dan hasil hijauan Rumput Panicum maksimum paling baik pada jarak tanama $10 \mathrm{~cm}$ x $20 \mathrm{~cm}(\mathrm{~J} 1)$ dengan dosis bio urin $7.5001 \mathrm{ha}^{-1}$ (D2) yaitu 7.90 ton $\mathrm{ha}^{-1}$ pada pemotongan ketiga.

Saran : Pada Peternak yang memakai pupuk bio urin untuk tanaman Rumput Panicum maximum disarankan menanam dengan jarak tanam $(10 \mathrm{~cm}$ x $20 \mathrm{~cm}$ ) dengan dosis $7.500 \mathrm{l} \mathrm{ha}^{-1}$ pada lahan kering. Perlu dilakukan penelitian lanjutan pada musim hujan.

\section{REFERENSI}

Adijaya, I.N., Yasa, I.M.R. 2007. Pemanfaatan Bio Urine dalam Produksi Hijauan Pakan Ternak (Rumput Raja). Prosiding Seminar
Nasional Dukung Inovasi Teknologi dan Kelembagaan dalam Mewujudkan Agribisnis Industri Pedesaan. Mataram, 22-23 Juli 2007. Balai Besar Pengkajian dan Pengembangan Teknologi Pertanian. Hal. 155-157. Horne, P.N. Sturr, W.W. 1999. Pengembangan Teknologi Hijauan Makanan Ternak. Bersama Petani Kecil (Terjemahan). Monografi ACIAR No.65.

Kerley, S. J., and Darvis, S.C. 1996. Preliminary Studies of the Impact of Excreted $\mathrm{N}$ on Cycling and Uptake of N in Pasture Systems Using Natural Abundance Stable Isotopic Discrimination. Plant and Soil .

Mc. Illroy, R.J. 1997. Pengantar Budidaya Padang Rumput Tropika. Jakarta: Penerbit Pradnya Paramita.

Nitis. 1980. Makanan Ternak Salah Satu Sarana untuk Meningkatkan Produksi Ternak. Pidato Pengukuhan Guru Besar Dalam Ilmu Makanan Ternak. Fakultas Kedokterah Hewan dan Peternakan Universitas Udayana.

Steel, R.G.D dan J.H. Torrie. 1993. Prinsip dan Prosedur Statistika. Suatu Pendekatan Biometrik. Terjemahan: Sumantri, B. Gramedia Pustaka Umum.Jakarta.

Poerwowidodo.1992. Telaah Kesuburan Tanah. Penerbit Angkasa. Bandung.

Widjajanto, D.W., Honmura, T., Matsushita, K., and Miyauchi, N. 2001. Studies on the Release of N From Water Hyacinth Incorporated Into SoilCrop System Using $15 \mathrm{~N}$-Labeling Tehniques. Pak. J.Biol.Sc. 